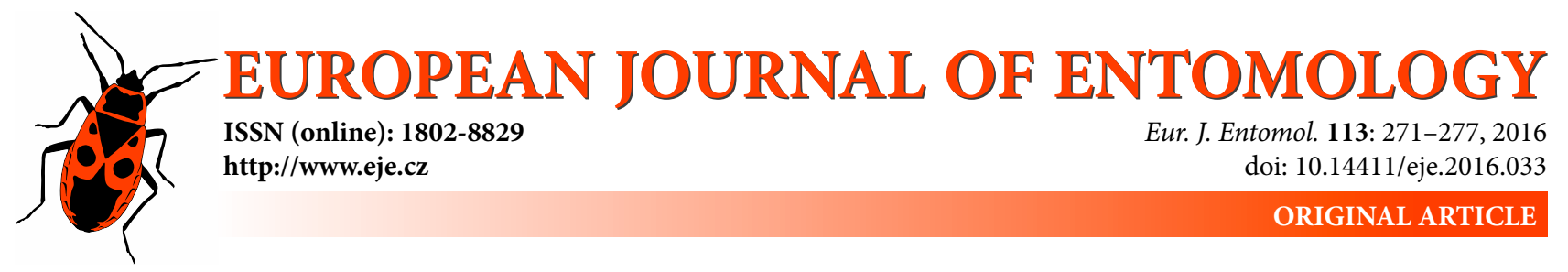

\title{
Mycobiota in the brood cells of the European beewolf, Philanthus triangulum (Hymenoptera: Crabronidae)
}

\author{
Tobias ENGL ${ }^{1}$, BetTINA BODENSTEIN ${ }^{2}$ and ERHARd STROHM² \\ 1 Johannes Gutenberg-University, Department of Evolutionary Ecology, Johann-Joachim-Becherweg 13, 55131 Mainz, \\ Rhineland-Palatinate, Germany; e-mail: tengl@uni-mainz.de \\ ${ }^{2}$ University of Regensburg, Department of Zoology, Universitätsstr. 31, 93040 Regensburg, Bavaria, Germany; \\ e-mails: 555-tini@gmx.de, erhard.strohm@biologie.uni-regensburg.de
}

Key words. Hymenoptera, Crabronidae, European beewolf, Philanthus triangulum, mass provision, antimicrobial, defense, mold fungi

\begin{abstract}
Mass provisioning insects have to cope with microbial spoilage of their food supplies. As their fitness is directly linked to the availability of high quality food for their offspring, they have evolved various mechanisms for preserving these resources. The European beewolf, Philanthus triangulum, uses several mechanisms to not only preserve the food for their larvae, paralyzed workers of the European honeybee, Apis mellifera, but also protect the larvae that develop on the stored food. To assess the spectrum of fungi that pose a threat to beewolf brood cells, we manipulated brood cells by removing the insect defenses. We monitored the subsequent fungal infestations that would have been prevented by the beewolf defense mechanisms and isolated and identified the mold fungi. The cosmopolitan and highly competitive species of Aspergillus, in particular A. flavus, dominated the mold in beewolf brood cells. All other infestations could also be attributed to generalist mold fungi that are commonly found in soil and also on insects. Our findings indicate that beewolf brood cells can be colonized by a broad range of opportunistic soil mold fungi. Thus, it seems highly adaptive that beewolves employ general, broad spectrum defense mechanisms.
\end{abstract}

\section{INTRODUCTION}

Many animals store large amounts of food for some time either for their own use during periods of food shortage or for their offspring (Smith \& Reichman, 1984; Vander Wall, 1990; Castleberry \& Castleberry, 2008). These food sources are highly prone to infestation by mold fungi and putrefying bacteria. In order to make the nutrients unsuitable for consumption by animals and monopolize the food, many mold fungi and bacteria have evolved toxins that render nutrients unsuitable or methods to rapidly decompose the food (Janzen, 1977; Burkepile et al., 2006). Once the microorganisms have established themselves on the food they might also infest the larvae or cocoons in the brood cells of their host. Mold fungi in particular pose a severe problem. They are cosmopolitan, produce a huge number of spores that can remain dormant yet viable for a very long time, produce potent toxins and grow very fast. Therefore, fungi often not only compete for resources with animals, but might even be considered as pathogens (Dowd et al., 1989; Wicklow \& Dowd, 1989; Rohlfs, 2008; Trienens et al., 2010).

Such threats by microorganisms resulted in the evolution of adaptations in animals to deal with microbial infestation and spoilage of stored food. One outcome is that some animals have evolved the capacity to digest decomposed food (Reichman et al., 1986) or even the microorganisms instead of the primary food source (Heseltine, 1965; Martin \& Weber, 1969; Yamaoka, 1996; Mueller et al., 2005). Alternatively, animals prevent the growth of fungi or bacteria on the food (Bienvenu et al., 1968; Rosengaus et al., 2000; Traniello et al., 2002; Cardoza et al., 2006; Rozen et al., 2008; Tragust et al., 2013; Wang et al., 2015).

In brood caring Hymenoptera, like many bees, ants and wasps, food stores and developing larvae are located in warm and humid nests or brood cells (Strohm \& Linsenmair, 2001) making them particularly prone to infestation by ubiquitous and highly competitive microorganisms (Janzen, 1977; Sherratt et al., 2006). The European beewolf Philanthus triangulum Fabricius, 1775, a solitary digger wasp hunts for workers of the European honeybee Apis mellifera Linnaeus, 1758. In response to the above threats, they have evolved several defense mechanisms to protect their food resources and larvae against microbial infestation. Females use glandular secretions (Strohm \& Linsenmair, 2001; Herzner \& Strohm, 2007; Herzner et al., 2007) and antibiotic substances produced by symbiotic actinobacteria (Kaltenpoth et al., 2005; Kroiss et al., 2010) to prevent spoilage of their food resources or their off- 
spring becoming infested. However, the mycobiota against which these defense mechanisms act remain unstudied. Females of the European beewolf impregnate paralyzed honey bees with a hydrocarbon rich secretion from their postpharyngeal gland before they place them in the brood cells (Strohm \& Linsenmair, 2001; Herzner et al., 2007). This secretion is not an antibiotic per se, but delays fungal germination by reducing the condensation of water on the bees until larvae are large enough to monopolize the bees and actively remove growing mycelia (Herzner \& Strohm, 2007). Prior to provisioning the brood cell, the females apply a whitish secretion from their antennae, which contains symbiotic Streptomyces bacteria, to the ceiling of the brood cell (Strohm \& Linsenmair, 1994; Kaltenpoth et al., 2005). When the larvae start to spin their cocoons, they take up the secretion from the brood cell wall and incorporate the bacteria into the cocoon. These Streptomyces bacteria produce at least nine antibiotic substances that protect the cocoon against microbes (Kaltenpoth \& Strohm, 2007; Kroiss et al., 2010).

To better understand the evolution of those defenses, we studied the microbiota that infest beewolf provisions and offspring. Since beewolves are solitary mass provisioners, there is no direct contact between mother and progeny and conspecifics except for mating. The indirect infection of offspring from their mother through the brood cell environment is highly unlikely as individuals would need to survive for several weeks or months and be strong enough to successfully provision new brood cells in order to pass the infection on to a new generation. Thus microbes have little opportunity to spread throughout a host population making it unlikely that there is a parasitic fungus that specializes on beewolves. The fungi found in beewolf brood cells, therefore, are most likely either unspecialized ubiquitous mold fungi or specialized pathogenic fungi of honeybees e.g. Ascosphaera apis L.S. Olive \& Splittoir, 1955 or diverse Aspergillus species, the causes of chalk brood and stone brood. Knowledge of the spectrum of fungi that infest beewolf brood cells will help in understanding the evolution of the diverse antifungal mechanisms employed by beewolves. We thus disabled the beewolf defenses by removing beewolf eggs from brood cells, thus giving molds more time to infest the bees in the cells. Beewolves are not all equally successful in acquiring Streptomyces symbionts and their protective antibiotic cocktail or are protected by an insufficient amount of antibiotics due to the variability in the cocktail (Koehler \& Kaltenpoth, 2013; Koehler et al., 2013). Consequently there are also naturally infested cocoons. The fungi that infested brood cells or cocoons were cultivated and then identified based on the amplification and sequencing of a small subunit of the rDNA gene (SSU) and the intergenic transcribed spacer region (ITS) and some morphological characteristics determined by light microscopy.
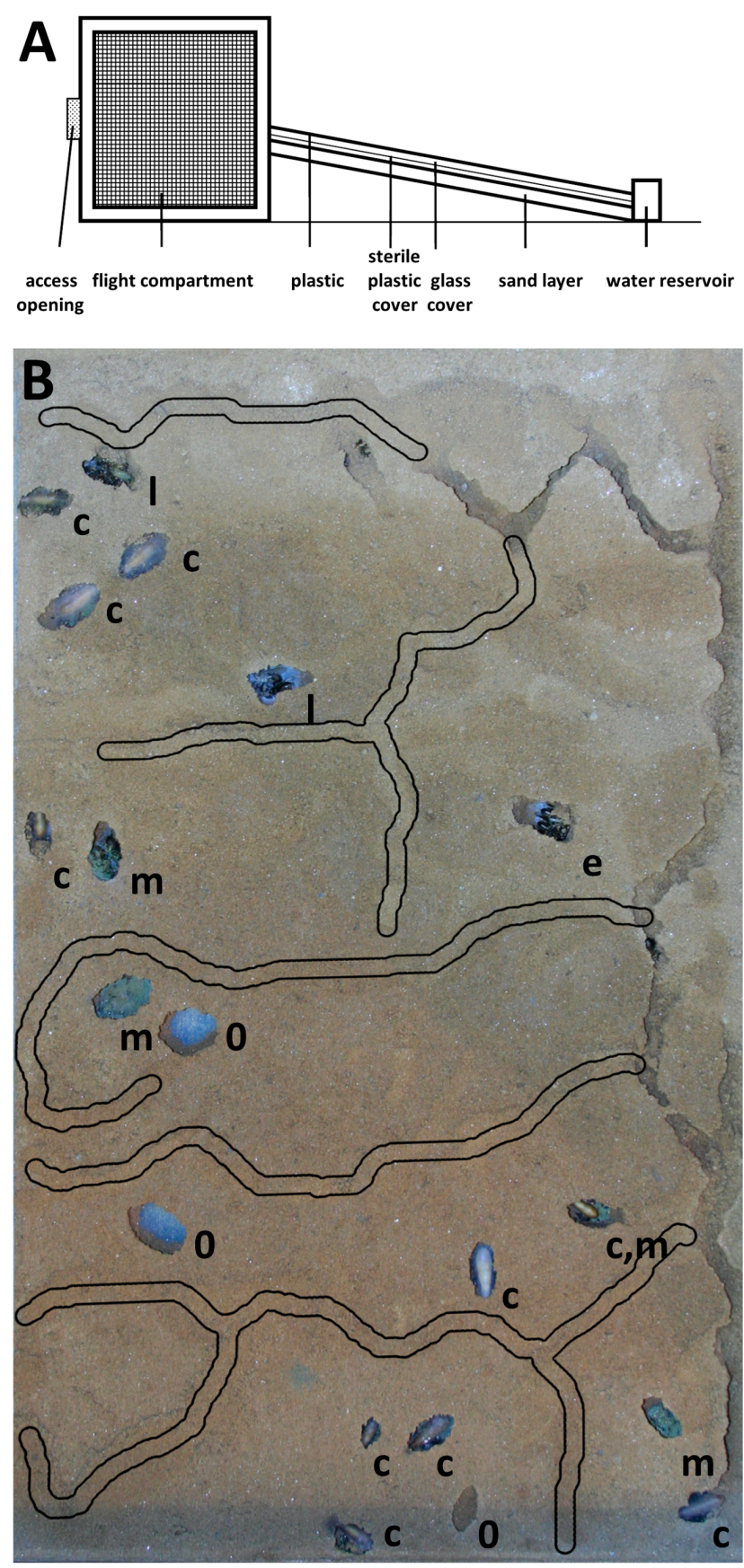

Fig. 1. Beewolf observation cage. A - schematic setup; B - sand compartment with all covers removed. Main burrow can be seen on the right side. Side burrows were closed by the beewolf female and are marked in black. Brood cells contain bees with an egg (e), a larva (I), a cocoon (c) or are infested with mold fungi $(\mathrm{m})$. Some brood cells are empty $(0)$, either because they were not provisioned by the female or the contents were removed for an experiment.

\section{MATERIALS AND METHODS}

\section{Isolation of fungi}

Beewolf females were caught in the field (university campus, Erlangen, Germany) and kept individually in observation cages in the laboratory (Fig. 1, Strohm \& Linsenmair, 1994) at approximately $27^{\circ} \mathrm{C}$ with a $14 \mathrm{~L}: 10 \mathrm{D}$ cycle. Environmental humidity was not controlled but the sand in the beewolf cages was watered from a reservoir at the lower end so a humidity gradient formed within the compartment, which allowed the females to freely decide where to construct their brood cells. 
For each female the observation cages were filled with fresh sand, which had not previously been used for rearing beewolves. The sand was obtained from a commercial supplier and stored for three years in a pile outside on the university campus under natural conditions. Other insects had access to this pile of sand as in natural beewolf nesting sites. The sand in each of the observation cages was covered with a new, thin, transparent plastic cover, a heavier glass cover and a non-transparent lid. The beewolves were provided with honeybee workers and honey ad libitum. To determine which mold fungi readily infest the provisioned bees beewolf eggs were removed from brood cells as intact brood cells are rarely infested with mold fungi in the field (5.3\%) (Strohm $\&$ Linsenmair, 2001). The paralyzed bees in provisioned brood cells were monitored visually daily through the plastic and glass covers for the occurrence of fungal infestations. In addition, 73 cocoons from un-manipulated brood cells were kept in open, sterile reaction tubes in a refrigerator at $4^{\circ} \mathrm{C}$. To obtain conidia from infested bees, brood cells were opened by removing the transparent covers. Infested bees were transferred from the brood cells and cocoons from the reaction tubes, and placed in sterile Petri dishes and single conidiophores were sampled under a dissecting microscope (Zeiss) using the tip of a sterile needle and then inoculated on Sabouraud-dextrose-agar (Odds, 1991) plates. If there was mold but no clearly identifiable conidiophores, hyphae were transferred to agar plates using sterile forceps. All isolates were incubated in the dark at $25^{\circ} \mathrm{C}$ until the formation of new mature conidiophores. If no contaminations of the agar plates were visible, single conidiophores were sampled from these colonies and spores transferred to new culture plates. This procedure was repeated three times to obtain pure strains. If no conidiophores developed some hyphae were transferred to new plates. Morphological characters of these fungal colonies were recorded.

To assess the frequency of the different fungal species in beewolf brood cells, a sample of 116 infested brood cells from ten nesting cages kept under identical conditions as described for the fungal isolation procedure were examined using a dissecting microscope (Zeiss). Based on the knowledge of the appearance of the fungi in the brood cells, the most frequent fungal infestations in the brood cells could easily be distinguished by visual inspection. Thus their frequency could be assessed without laborious cultivation and molecular identification.

\section{DNA preparation, PCR, sequencing}

Freshly inoculated, still growing mycelia were sampled using tweezers, frozen in liquid nitrogen and manually crushed with sterile pipette tips. DNA was isolated using the Epicentre MasterPure Kit (Epicentre, Madison, USA). We amplified two genetic sequences: the small subunit of nuclear rDNA and the internal transcribed spacer region (using primer pairs nuSSU 0817 \& 1536 from Borneman and Hartin, 2000; NS1\&4 and ITS1\&4 from Weisburg et al., 1991).

PCR was done using a Biometra TGradient thermo cycler in a total volume of $12.5 \mu \mathrm{L}$ with $1 \mu \mathrm{L}$ of DNA sample and $1 \times \mathrm{PCR}$ buffer [50 mM Tris- $\left.\mathrm{HCl} \mathrm{pH} 9.1,14 \mathrm{mM}\left(\mathrm{NH}_{4}\right)_{2} \mathrm{SO}_{4}\right], 3 \mathrm{mM}$ $\mathrm{MgCl}_{2}$, each $240 \mu \mathrm{M} \mathrm{dNTPs,} 10 \mathrm{pmol}$ of each primer and 0.5 $\mathrm{U}$ of Taq DNA polymerase (Peqlab). Cycle parameters were as follows: $3 \mathrm{~min}$ at $95^{\circ} \mathrm{C}$ followed by 35 cycles of $95^{\circ} \mathrm{C}$ for $1 \mathrm{~min}$, TA for $1 \mathrm{~min}$ and $72^{\circ} \mathrm{C}$ for $1 \mathrm{~min}$, and a final extension time of 5 min at $72^{\circ} \mathrm{C}$. TA was $56^{\circ} \mathrm{C}$ for the NS primer pair, $58^{\circ} \mathrm{C}$ for the ITS and nu primer pair. PCR products were purified using the PeqGOLD MicroSpin cyle-Pure kit (Peqlab, Germany) and sent to Seqlab, Göttingen for sequencing.

\section{Microscopy}

To facilitate the differentiation of the species of Aspergillus, a Leica DMLS light microscope equipped with phase contrast was used to determine their morphological characters like conidia size and texture (Diba et al., 2007).

\section{RESULTS AND DISCUSSION}

Only a few mold fungi were recorded infesting beewolf brood cells. All of them are cosmopolitan opportunists. The most frequently recorded were species of the section Flavi of the genus Aspergillus, followed by Gymnascella

Table 1. Results of the genetic identification of the nine fungal species isolated from beewolf brood cells. The sequences obtained from the beewolf brood cell isolates are stored at the NCBI under the GenBank accession numbers given in the table. In the last column, is the percentage of identical bases in the sequence of the isolate and that of the species with the closest match.

\begin{tabular}{|c|c|c|c|c|c|}
\hline $\begin{array}{l}\text { Isolated } \\
\text { species }\end{array}$ & Origin & Sequence & Accession numbers & Closest match & Identity \\
\hline 1 & brood cell & $\begin{array}{l}\text { SSU } \\
\text { ITS }\end{array}$ & $\begin{array}{l}\text { JF824683 } \\
\text { JF824682 }\end{array}$ & $\begin{array}{l}\text { Aspergillus flavus } \\
\text { Aspergillus flavus }\end{array}$ & $\begin{array}{l}100 \% \\
100 \%\end{array}$ \\
\hline 2 & brood cell & $\begin{array}{l}\text { SSU } \\
\text { ITS }\end{array}$ & $\begin{array}{l}J F 824685 \\
J F 824684\end{array}$ & $\begin{array}{l}\text { Aspergillus tamarii } \\
\text { Aspergillus tamarii }\end{array}$ & $\begin{array}{l}100 \% \\
100 \%\end{array}$ \\
\hline 3 & brood cell & $\begin{array}{l}\text { SSU } \\
\text { ITS }\end{array}$ & $\begin{array}{l}\text { JF824687 } \\
\text { JF824686 }\end{array}$ & $\begin{array}{l}\text { Aspergillus nomius } \\
\text { Aspergillus nomius }\end{array}$ & $\begin{array}{c}99.49 \% \\
100 \%\end{array}$ \\
\hline 4 & brood cell & $\begin{array}{l}\text { SSU } \\
\text { ITS }\end{array}$ & $\begin{array}{l}\text { JF824689 } \\
\text { JF824688 }\end{array}$ & $\begin{array}{l}\text { Rollandina hyalinospora* } \\
\text { Gymnascella hyalinospora* }\end{array}$ & $\begin{array}{l}99.37 \% \\
98.91 \%\end{array}$ \\
\hline 5 & brood cell & $\begin{array}{l}\text { SSU } \\
\text { ITS }\end{array}$ & $\begin{array}{l}J F 824691 \\
J F 824690\end{array}$ & $\begin{array}{l}\text { Paecilomyces lilacinus }{ }^{*} \\
\text { Paecilomyces lilacinus }\end{array}$ & $\begin{array}{l}100 \% \\
100 \%\end{array}$ \\
\hline 6 & brood cell & $\begin{array}{l}\text { SSU } \\
\text { ITS }\end{array}$ & $\begin{array}{l}\text { JF824693 } \\
\text { JF824692 }\end{array}$ & $\begin{array}{l}\text { Cunninghamella echinulata } \\
\text { Cunninghamella echinulata }\end{array}$ & $\begin{array}{l}98.47 \% \\
99.53 \%\end{array}$ \\
\hline 7 & cocoon & $\begin{array}{l}\text { SSU } \\
\text { ITS }\end{array}$ & $\begin{array}{l}\text { JF824695 } \\
\text { JF824694 }\end{array}$ & $\begin{array}{l}\text { Actinomucor elegans } \\
\text { Actinomucor elegans }\end{array}$ & $\begin{array}{c}99.46 \% \\
100 \%\end{array}$ \\
\hline 8 & cocoon & $\begin{array}{l}\text { SSU } \\
\text { ITS }\end{array}$ & $\begin{array}{l}\text { JF824697 } \\
\text { JF824696 }\end{array}$ & $\begin{array}{l}\text { Fusarium oxysporum } \\
\text { Fusarium redolens }\end{array}$ & $\begin{array}{c}99.93 \% \\
100 \%\end{array}$ \\
\hline 9 & cocoon & $\begin{array}{l}\text { SSU } \\
\text { ITS }\end{array}$ & $\begin{array}{l}\text { JF824699 } \\
\text { JF824698 }\end{array}$ & $\begin{array}{l}\text { Cunninghamella elegans } \\
\text { Cunninghamella elegans }\end{array}$ & $\begin{array}{l}99.05 \% \\
98.27 \%\end{array}$ \\
\hline
\end{tabular}

* Rollandiana hyalinospora and Gymnascella hyalinospora are both commonly used for the same species; ** Now designated as Purpuroecillium lilacinum (Luangsa-Ard et al., 2011); ${ }^{* * *}$ Fusarium redolens is a variety of Fusarium oxysporum. 


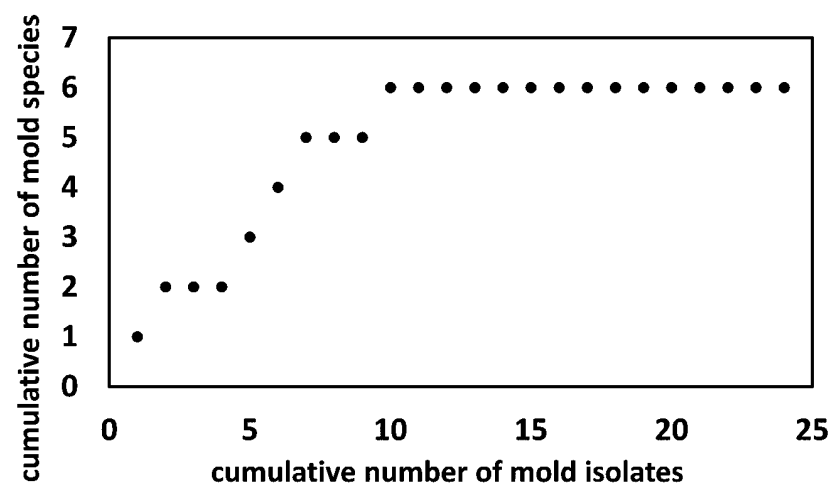

Fig. 2. Rarefaction curve showing dependence of the number of mold fungi identified on the number of isolate from beewolf brood cells examined.

hyalinospora Currah, 1985. The remaining infestations recorded at low frequencies were those of Purpureocillium lilacinum Luangsa-Ard, Houbraken, Hywel-Jones \& Samson, 2011 and Cunninghamella echinulata Thaxt, 1903. Only three species of molds were recorded infesting cocoons: Actinomucor elegans Benjamin \& Hesseltine, 1957, Fusarium oxysporum Schlechtendahl, 1824 and Cunninghamella elegans Lendner, 1905.

In beewolf brood cells that were sampled prior to cocoon spinning, six species of fungi were recorded in 24 isolates from 19 brood cells of 8 different beewolf females (Table
1). The low diversity of mold fungi infesting beewolf brood cells was initially surprising. However, all six species were found in the first ten isolates at which point the rarefaction curve reaches its plateau (Fig. 2). Further monitoring of a total of 56 brood cells of 20 females didn't reveal any morphologically different infestations. Based on the ITS and $18 \mathrm{~S}$ rRNA sequences, 11 isolates were assigned to the genus Aspergillus (Eurotiales: Trichocomaceae) and the section Flavi (Peterson, 2008), with 7 isolates tentatively identified as Aspergillus flavus Link, 1809, oryzae Cohn, 1884 or parasiticus Speare, 1912, two as A. tamari Kita, 1913 and two as $A$. nomius Kurtzman, Horn \& Hesseltine, 1987. We supplemented the lack of resolution power of the ITS and 18S rDNA sequences for discriminating between species in the dominant Aspergillus section Flavi isolates by microscopic examinations. The isolates assigned to $A$. flavus, A. oryzae and A. parasiticus produced globose conidia, $3.6 \mu \mathrm{m}$ in diameter with a smooth surface and brown stipes, which are not characters typical of $A$. oryzae and $A$. parasiticus. Thus, it is likely that all of these isolates are of A. flavus. Bees infested with Aspergillus fungi were usually completely overgrown and the fungi formed a dense cover of dark greenish (A. flavus) or brown (A. tamari) spores.

A. flavus, A. nomius and $A$. tamarii are reported as cosmopolitan soil fungi, or molds on stored food and $A$. flavus and $A$. tamarii are pathogens of insects, including solitary
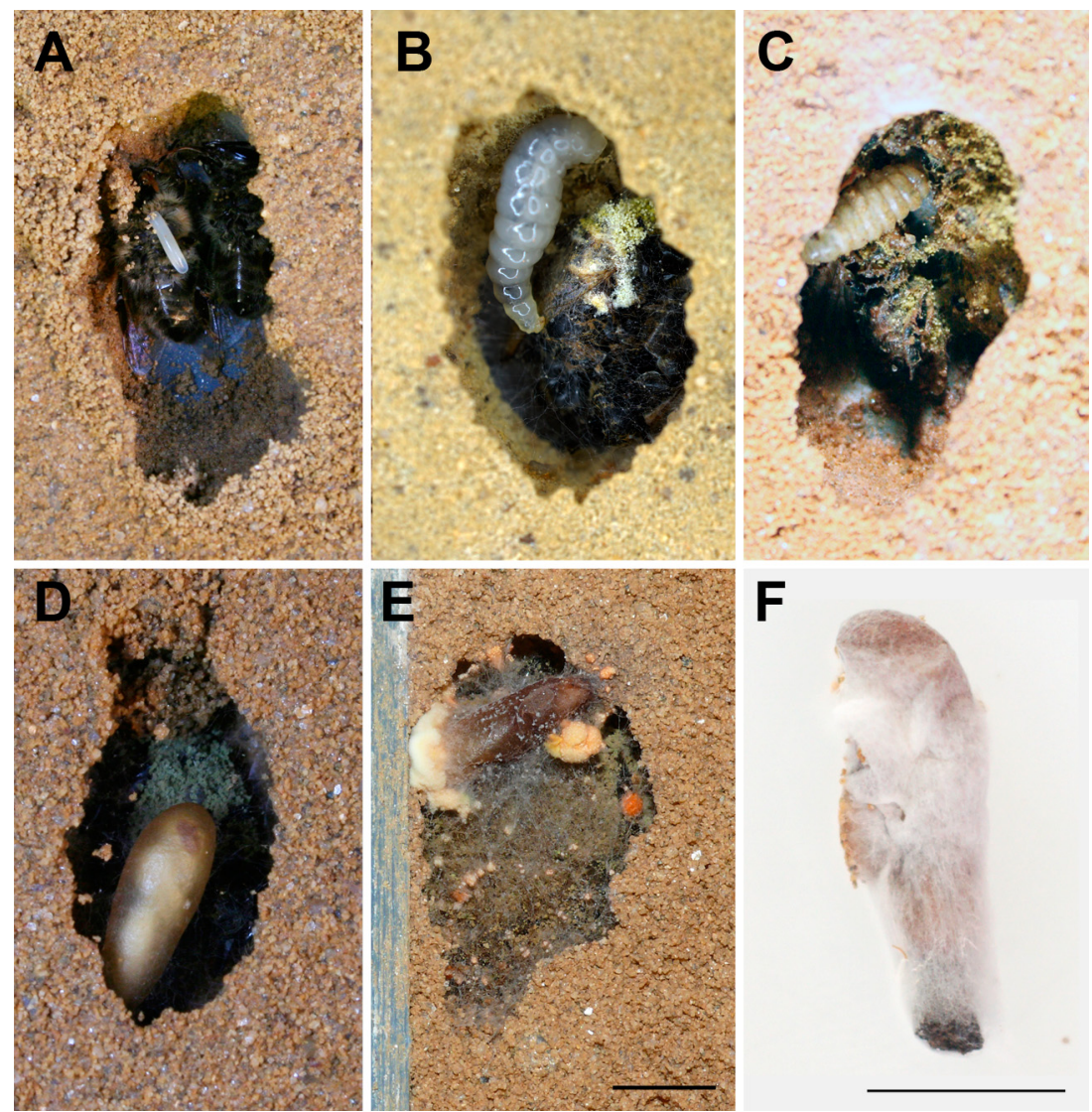

Fig. 3. Brood cells of the European beewolf, P. triangulum. A - fresh brood cell containing two European honeybee, A. mellifera, workers and one beewolf egg; B - beewolf larva starting to spin its cocoon on bees that are already infested with Aspergillus sp.; C - brood cell with a dead beewolf larva and a severe infestation of Aspergillus sp.; D - beewolf pupa inside its cocoon. The bee remains underneath are also infested with Aspergillus sp. E - brood cell and cocoon infested with Aspergillus sp. and G. hyalinospora (orange and red); F infested overwintering cocoon taken out of a reaction tube. Scale bars are each $1 \mathrm{~cm}$. 
bees (Batra et al., 1973) and honey bees (Batra et al., 1973; Gilliam et al., 1974, 1977, 1989; Domsch et al., 1980; Wicklow \& Dowd, 1989; Gilliam, 1997), A. flavus, especially, can be a serious brood pathogen causing the disease of honeybee larvae, known as stonebrood (Burnside \& Library, 1927; Gilliam et al., 1974). In addition to being able to grow on a broad range of substrates (Fogarty, 1994), their ability to produce carcinogenic and toxic aflatoxins as well as a broad range of other toxic substances (Brase et al., 2009; Klich, 2009) makes members of the genus Aspergillus strong competitors.

Three other isolates with morphologically very similar colonies were genetically identical and tentatively identified as Gymnascella hyalinospora Currah, 1985 (Onygenales: Gymnoascaceae). There is little information on this species and its close relatives except that they seem to be opportunistic detrivores (Currah, 1994). Of the remaining isolates, one was most similar to Purpureocillium lilacinum (formerly Paecilomyces lilacinus, Hypocreales: Ophiocordicipitaceae; Luangsa-Ard et al., 2011) and another to Cunninghamella echinulata (Mucorales: Cunninghamellaceae), both of which are also opportunistic fungi commonly found in soil, on plants and insects, including bees (Domsch et al., 1980). Interestingly P. lilacinum and close relatives in the genus Cordyceps are parasites of nematodes (Jatala et al., 1979; Fiedler \& Sosnowska, 2007; Oclarit \& Cumagun, 2009), insects (Sung et al., 2007) and insect eggs (Storey et al., 1991). P. lilacinum and G. hyalinospora nearly always occurred with another fungus, mostly Aspergillus (Fig. 3). The resolution power of the ITS and 18S rRNA sequences was insufficient for species level identification of most isolates. However, as these mold fungi were only present at low frequencies, the species level identification is of minor importance compared to the fungi of the genus Aspergillus and G. hyalinospora, which were the most frequently recorded species in the brood cells. Of the samples from the 116 visually examined beewolf brood cells $59 \%(\mathrm{~N}=66)$ were infested with species of Aspergillus and $26 \%(\mathrm{~N}=30)$ with $G$. hyalinospora. The remaining $15 \%(\mathrm{~N}=20)$ were infested with the other species. In most brood cells there was only one dominant fungus. In those cases where there were two different fungi one always belonged to the genus Aspergillus.

On hibernating cocoons we recorded three further opportunistic mold species (Domsch et al., 1980) that are most similar to Actinomucor elegans (Mucorales: Mucoraceae), Cunninghamella elegans (Mucorales: Cunninghamellaceae) and Fusarium oxysporum (Hypocreales: Nectriaceae). These species were not recorded infesting brood cells during the larval stage. All of the above plus $C$. echinulata formed a distinctive, extended, white mycelium without prominent sporophores, which enveloped the cocoon or filled the entire brood cell as well enveloping the bees or cocoons.

As in this study, cosmopolitan, generalist soil fungi, especially $A$. flavus is the most prevalent and devastating fungus, followed by $A$. tamari and P. lilacinum, in brood cells of the alkali bee Nomia melanderi Cockerell, 1906
(Batra et al., 1973). As alkali bees construct their nests in sandy soils like beewolves, but provision their progeny with pollen and nectar, the similarity in the spectrum of fungi infesting their brood cells and the most common fungi in honey bee hives, indicate that soil and bees are the major sources of fungal spores. The specific combination of mold species recorded in this study and by Batra et al. (1973) will not be globally representative for beewolves or other insects with a similar breeding ecology, but the general pattern of local and mostly opportunistic yet highly competitive mold fungi infesting the brood of insects with this quite common breeding strategy will be (Vander Wall, 1990; Castleberry \& Castleberry, 2008).

The fungi isolated from the beewolf brood cells are generalists that are able to grow on a variety of organic substances. Generally, fungi that are best adapted to the temperature and humidity in the brood cells and bees as a food source will outcompete others and dominate a brood cell (Dighton et al., 1992). This could have a devastating effect on beewolf offspring because if the infestation develops quickly the provisioned bees are usually completely covered by mold fungi (Fig. 3). Without the protection provided by the Streptomyces symbiont development inside the cocoon is also endangered (Fig. 3). If cocoons are not defended against mold fungi by experimentally removing the symbionts from brood cells before the larvae can acquire them, their chance of survival decreases during metamorphosis inside the cocoon from $83.3 \%$ to $6.7 \%$ (Kaltenpoth et al., 2005). But even an infestation at a later stage, which enables larvae to develop and spin their protective cocoon containing the symbionts, has an adverse effect in reducing the food supply, which is especially serious for female beewolves as there might be insufficient food for them to achieve a body size large enough to enable them to bring paralyzed honeybees back to provision the next generation of offspring or are at least to perform badly in this respect (Strohm \& Linsenmair, 1997).

The threat posed by a diverse and an unpredictable spectrum of opportunistic fungi has probably shaped the beewolves' defense against these microorganisms. Both of the known defense mechanisms, the embalming of the prey and the antibiotics that are produced by the bacteria in the cocoon are rather unspecific. Embalming the honeybee prey by encasing them in a thick layer of hydrocarbons reduces the condensation of water on the surface of the bees and, thus, makes the conditions for the germination and growth of fungi less favourable (Herzner \& Strohm, 2007; Herzner et al., 2007; Strohm et al., 2007). However, this treatment constitutes a significant investment of resources for beewolf females (Herzner et al., 2001). As most fungi can only thrive in moist conditions, adaptations to overcome this defense mechanism would require a number of profound evolutionary changes that would, e.g., enable them to store sufficient water within the spores, draw water more efficiently from air or germinate in dry conditions. The symbiotic Streptomyces bacteria in the cocoon produce a mixture of at least nine different antibiotics (Kroiss et al., 2010). The entire "cocktail" has a broad range of inhibi- 
tory activity that is achieved by combining complementary strain specific inhibition of single components (Kroiss et al., 2010). This combination therapy is effective against a wide range of opportunistic and entomopathogenic fungi and bacteria, including A. flavus and F. oxysporum (Kaltenpoth et al., 2005, 2006; Kroiss et al., 2010).

Beewolf brood cells are a rare and unpredictable opportunity for the opportunistic fungi that are an important threat to beewolf progeny to reproduce. Thus, the infestation of beewolf brood cells is of negligible importance for these fungi and there is little selective pressure for them to evolve counter adaptations against the defense mechanisms of beewolves. In consequence, it is unlikely that there is an ongoing arms race between beewolves and fungi as would be expected in the case of a specialized parasite (Strohm \& Linsenmair, 2001) and the beewolves' defense mechanisms are directed against a large spectrum of potential pathogens rather than against a few specific pathogens.

\section{REFERENCES}

Batra L.R., Batra S.W.T. \& Bohart G.E. 1973: Mycoflora of domesticated and wild bees (Apoidea). - Mycopathol. Mycol. Appl. 49: 13-44.

Bienvenu R.J., Atchison F.W. \& Cross E.A. 1968: Microbial inhibition by prepupae of the alkali bee, Nomia melanderi. - $J$. Invertebr. Pathol. 12: 278-282.

Borneman J. \& HaRTin R.J. 2000: PCR primers that amplify fungal rRNA genes from environmental samples. - Appl. Environ. Microbiol. 66: 4356-4360.

Brase S., Encinas A., Keck J. \& Nising C.F. 2009: Chemistry and biology of mycotoxins and related fungal metabolites. Chem. Rev. 109: 3903-3990.

Burkepile D.E., Parker J.D., Woodson C.B., Mills H.J., KubaneK J., Sobecky P.A. \& Hay M.E. 2006: Chemically mediated competition between microbes and animals: Microbes as consumers in food webs. - Ecology 87: 2821-2831.

Burnside C.E. 1927: Saprophytic fungi associated with the honey bee. - Pap. Mich. Acad. Sci. Arts Lett. 8: 59-86.

Cardoza Y.J., Klepzig K.D. \& Raffa K.F. 2006: Bacteria in oral secretions of an endophytic insect inhibit antagonistic fungi. Ecol. Entomol. 31: 636-645.

Castleberry N.L. \& Castleberry S.B. 2008: Food selection and caching behavior. In Peles J.D. \& Wright J. (eds): The Allegheny Woodrat. Springer, New York, pp. 93-106.

CurRaH R.S. 1994: Peridial morphology and evolution in the prototunicate ascomycetes. In Hawksworth D.L. (ed.): Ascomycete Systematics. Problems and Perspectives in the Nineties. NATO ASI Series vol. 269, Plenum Press, New York, pp. 281-293.

Diba K., Kordbacheh P., Mirhendi S.H. \& Rezaie S. \& MahmouDI M. 2007: Identification of Aspergillus species using morphological characteristics. - Pak. J. Med. Sci. 23: 867-872.

Dighton J., White J. \& Oudemans P. 1992: The Fungal Community: Its Organization and Role in the Ecosystem. Taylor \& Francis, Baton Rouge, NY, 960 pp.

Domsch K.H., Gams W. \& Anderson T.-H. 1980: Compendium of Soil Fungi. Academic Press, London, 672 pp.

Dowd P.F., Miller J.D. \& Greenhalgh R. 1989: Toxicity and interactions of some Fusarium graminearum metabolites to caterpillars. - Mycologia 81: 646-650.

FiedLer Z. \& SosnowsKa D. 2007: Nematophagous fungus Paecilomyces lilacinus (Thom) Samson is also a biological agent for control of greenhouse insects and mite pests. - BioControl 52: $547-558$.
FogarTy W.M. 1994: Enzymes of the genus Aspergillus. In Smith J.E. (ed.): Aspergillus Biotechnology Handbook. Plenum, New York, $177 \mathrm{pp}$.

GiLliam M. 1997: Identification and roles of non-pathogenic microflora associated with honeybees. - FEMS Microbiol. Lett. 155: $1-10$.

Gilliam M., Prest D.B. \& Morton H.L. 1974: Fungi isolated from honey bees, Apis mellifera, fed 2,4-D and antibiotics. J. Invertebr. Pathol. 24: 213-217.

Gilliam M., Morton H.L., Prest D.B., Martin R.D. \& WickerHAM L.J. 1977: The mycoflora of adult worker honeybees, Apis mellifera: Effects of 2,4,5-T and caging of bee colonies. $-J$. Invertebr. Pathol. 30: 50-54.

Gilliam M., Prest D.B. \& Lorenz B.J. 1989: Microbes from apiarian sources: Molds in frass from larvae of the greater wax moth, Galleria mellonella. - J. Invertebr. Pathol. 54: 406408.

Herzner G. \& Strohm E. 2007: Fighting fungi with physics: Food wrapping by a solitary wasp prevents water condensation. - Curr. Biol. 17: R46-R47.

Herzner G., Schmitt T., Peschke K., Hilpert A. \& Strohm E. 2007: Food wrapping with the postpharyngeal gland secretion by females of the European beewolf Philanthus triangulum. J. Chem. Ecol. 33: 849-859.

Herzner G., Engl T. \& Strohm E. 2011: The cryptic combat against competing microbes is a costly component of parental care in a digger wasp. - Anim. Behav. 82: 321-328.

Heseltine C.W. 1965: A millenium of fungi, food and fermentation. - Mycologia 57: 149-197.

JANZEN D.H. 1977: Why fruits rot, seeds mold, and meat spoils. - Am. Nat. 111: 691-713.

Jatala P., Kaltenbach R. \& Bocangel M. 1979: Biological control of Meloidogyne incognita acrita and Globodera pallida on potatoes. - J. Nematol. 11: 303.

Kaltenpoth M. \& Strohm E. 2007: Life within insect antennae: Symbiotic bacteria protect wasp larvae against fungal infestation. - Comp. Biochem. Physiol. (A) 146: S65-S66.

Kaltenpoth M., Gottler W., Herzner G. \& Strohm E. 2005: Symbiotic bacteria protect wasp larvae from fungal infestation. - Curr. Biol. 15: 475-479.

Kaltenpoth M., Goettler W., Dale C., Stubblefield J.W., Herzner G., Roeser-Mueller K. \& Strohm E. 2006: "Candidatus Streptomyces philanthi", an endosymbiotic streptomycete in the antennae of Philanthus digger wasps. - Int. J. Syst. Evol. Microbiol. 56: 1403-1411.

KLICH M.A. 2009: Health effects of Aspergillus in food and air. Toxicol. Ind. Health. 25: 657-667.

Koenler S. \& Kaltenpoth M. 2013: Maternal and environmental effects on symbiont-mediated antimicrobial defense. $-J$. Chem. Ecol. 39: 978-988.

Koehler S., Doubsky J. \& Kaltenpoth M. 2013: Dynamics of symbiont-mediated antibiotic production reveal efficient longterm protection for beewolf offspring. - Front. Zool. 10: 3 .

Kroiss J., Kaltenpoth M., Schneider B., Schwinger M.G., Hertweck C., Maddula R.K., Strohm E. \& Svatos A. 2010: Symbiotic streptomycetes provide antibiotic combination prophylaxis for wasp offspring. - Nat. Chem. Biol. 6: 261-263.

Luangsa-Ard J., Houbraken J., van Doorn T., Hong S.-B., Borman A.M., Hywel-Jones N.L. \& SAmson R.A. 2011: Purpureocillium, a new genus for the medically important Paecilomyces lilacinus. — FEMS Microbiol. Lett. 321: 141-149.

Martin M.M. \& Weber N.A. 1969: The cellulose-utilizing capability of the fungus cultured by the attine ant Atta colombica tonsipes. - Ann. Entomol. Soc. Am. 62: 1386-1387. 
Mueller U.G., Gerardo N.M., Aanen D.K., Six D.L. \& Schultz T.R. 2005: The evolution of agriculture in insects. - Annu. Rev. Ecol. Evol. Syst. 36: 563-595.

OCLARIT E.L. \& CUMAgun C.J.R. 2009: Evaluation of efficacy of Paecilomyces lilacinus as biological control agent of Meloidogyne incognita attacking tomato. - J. Plant Prot. Res. 49 : 337-340.

OdDs F.C. 1991: Sabouraud('s) agar. - J. Med. Vet. Mycol. 29: $355-359$.

Peterson S.W. 2008: Phylogenetic analysis of Aspergillus species usnig DNA sequences from four loci. - Mycologia 100: 205-226.

Reichman O.J., Fattaey A. \& Fattaey K. 1986: Management of sterile and moldy seeds by a desert rodent. - Anim. Behav. 34: 221-225.

RoHLfs M. 2008: Host-parasitoid interaction as affected by interkingdom competition. - Oecologia 155: 161-168.

Rosengaus R.B., Lefebvre M.L. \& Traniello J.F.A. 2000: Inhibition of fungal spore germination by Nasutitermes: Evidence for a possible antiseptic role of soldier defensive secretions. J. Chem. Ecol. 26: 21-39.

Rozen D.E., Engelmoer D.J.P. \& SMiseth P.T. 2008: Antimicrobial strategies in burying beetles breeding on carrion. - Proc. Natl. Acad. Sci. U.S.A. 105: 17890-17895.

Sherratt T.N., Wilkinson D.M. \& Bain R.S. 2006: Why fruits rot, seeds mold and meat spoils: A reappraisal. — Ecol. Model. 192: 618-626.

Smith C.C. \& Reichman O.J. 1984: The evolution of food caching by birds and mammals. - Annu. Rev. Ecol. Syst. 15: 329-351.

Storey G.K., Aneshansley D.J. \& EIsner T. 1991: Parentally provided alkaloid does not protect eggs of Utetheisa ornatrix (Lepidoptera, Arctiidae) against entomopathogenic fungi. - $J$. Chem. Ecol. 17: 687-693.

Strohm E. \& Linsenmair K.E. 1994: Leaving the cradle: How beewolves (Philanthus triangulum F.) obtain the necessary spatial information for emergence. — Zoology (Jena) 98: 137146.

Strohm E. \& Linsenmair K.E. 1997: Female size affects provisioning and sex allocation in a digger wasp. - Anim. Behav. 54: $23-34$.
Strohm E. \& Linsenmair K.E. 2001: Females of the European beewolf preserve their honeybee prey against competing fungi. - Ecol. Entomol. 26: 198-203.

Strohm E., Herzner G. \& Goettler W. 2007: A "social” gland in a solitary wasp? The postpharyngeal gland of female European beewolves (Hymenoptera, Crabronidae). - Arthropod Struct. Dev. 36: 113-122.

Sung G.H., Hywel-Jones N.L., Sung J.M., Luangsa-Ard J.J., Shrestha B. \& Spatafora J.W. 2007: Phylogenetic classification of Cordyceps and the clavicipitaceous fungi. - Stud. Mycol. 57: 5-59.

Tragust S., Mitteregger B., Barone V., Konrad M., Ugelvig Line V. \& CREMER S. 2013: Ants disinfect fungus-exposed brood by oral uptake and spread of their poison. - Curr. Biol. 23: 76-82.

Traniello J.F.A., Rosengaus R.B. \& Savoie K. 2002: The development of immunity in a social insect: Evidence for the group facilitation of disease resistance. - Proc. Natl. Acad. Sci. U.S.A. 99: 6838-6842.

Trienens M., Keller N.P. \& Rohlfs M. 2010: Fruit, flies and filamentous fungi - experimental analysis of animal-microbe competition using Drosophila melanogaster and Aspergillus mould as a model system. - Oikos 119: 1765-1775.

VANDER Wall S.B. 1990: Food Hoarding in Animals. University of Chicago Press, Chicago, IL, 455 pp.

Wang L., Feng Y., Tian J., Xiang M., Sun J., Ding J., Yin W.-B., Stadler M., Che Y. \& LiU X. 2015: Farming of a defensive fungal mutualist by an attelabid weevil. - ISME J. 9:1793-1801.

Weisburg W.G., Barns S.M., Pelletier D.A. \& Lane D.J. 1991: $16 \mathrm{~S}$ ribosomal DNA amplification for phylogenetic study. $-J$. Bacteriol. 173: 697-703.

WickLOw D.T. \& DowD P.F. 1989: Etomotoxigenic potential of wild and domesticated yellow-green Aspergilli - toxicity to corn-earworm and fall armyworm larvae. - Mycologia 81: 561-566.

YAMAOKa I. 1996: Symbiosis in termites. In Colwell R.R., Simidu U. \& Ohwada K. (eds): Microbial Diversity in Time and Space. Springer, New York, pp. 65-70.

Received June 2, 2015; revised and accepted March 3, 2016 Published online March 21, 2016 